\title{
EFFECT OF GLASS CONTAINERS ON THE ELECTROMO- TIVE FORCE OF WESTON NORMAL CELLS
}

\author{
By G. W. Vinal and M. Langhorne Howard
}

\section{ABSTRACT}

Improvements in the reproducibility and constancy of electromotive force (emf) of Weston normal cells have resulted from many previous researches, but little attention has hitherto been given to effects which may be produced by the glass containers. Accelerated experiments have now been made by adding samples of glass in powdered form to the mercurous-sulphate paste and the resulting effects have been found to parallel the behavior of other cells which have been under observation for longer periods of time. Various chemical compounds have also been added to the paste to test their effects on emf of the cells. Some of these materials have caused abnormal hysteresis and temperature coefficients. The glass containers have been redesigned with a view to improving the constancy and portability of the cells.

\section{CONTENTS}

I. Introduction

II. Preparation of experimental cells

III. Measurements of electromotive force

IV. Factors affecting the electromotive force and constancy of cells

1. Effect of unequal acid concentrations in the positive and negative limbs

2. Effect of glass on the constancy of

(a) Neutral cells

3. Effect of materials added as impurities to the paste

3. Effect of materials added as impurities to the paste
(a) Neutral cells

4. Effect of impurities on hysteresis and temperature coefficient_..............

V. Improvements in the design of standard-cell blanks

VI. Discussion of the results

VII. Summary

\section{INTRODUCTION}

The importance of the Weston normal cell as a standard of emf is ample justification for continued efforts to improve its reproducibility and constancy. Many previous publications have been devoted to the preparation and purification of the materials used in constructing these cells. Pure materials are required to insure the reproducibility of cells to within a few microvolts. Although no adequate specifications for the materials have been adopted, the methods are now generally understood and a high degree of reproducibility of emf has been attained at the various national and other laboratories. 
Constancy of emf during many years when the cells are preserved and measured under proper conditions is as important as the reproducibility of newly made cells. Constancy depends on stabilized conditions within the cell. The active materials must be stable, and they must be free from contamination by other materials that are structurally part of the cell.

Variations observed in the emf have usually been attributed to hydrolysis of mercurous sulphate employed as the depolarizer. As a remedy for this difficulty some authors ${ }^{1}$ have added sulphuric acid, in varying amounts to the electrolyte. Others ${ }^{2}$ have favored the construction of neutral cells, however, believing the presence of acid to be objectionable. A diversity of opinion is evident. Hydrolysis of the mercurous sulphate does not appear to take place to the same extent in all cells. Some neutral cells made in 1906 are still in good condition while others made more recently have been discarded as no longer useful. Smith, ${ }^{3}$ who favored the use of acid in the cells, has stated that "the mere hydrolysis of mercurous sulphate does not afford a complete explanation of the changes (in emf) commonly observed and that there was evidence of another disturbing agency." He has assumed that a complex ion is formed and that this is partly responsible for the changes.

Shaw and Reilley ${ }^{4}$ have reviewed nine possible explanations which have been suggested for "aging" of Weston normal cells and conclude that the most probable is the introduction of foreign ions from the glass container of the cell by slow solution and diffusion.

Few authors have mentioned the kind or quality of the glass which they have employed in making the cells. Von Steinwehr ${ }^{5}$ has stated, however, that in order to hold the acidity within the cell constant, it is necessary to choose the proper kind of glass, avoiding the varieties which would render the electrolyte alkaline.

The necessity for platinum wires passing through the glass walls of the cell to provide electrical contact with the electrodes has imposed limitations on the kind of glass which can be employed, because the wire must be hermetically sealed. The type of construction which has been used at the Bureau has been described previously. ${ }^{6}$ In making the glass containers, a molten bead of lead glass on a platinum wire was pushed into the side wall of the cell, so that the lead glass formed a sleeve covering the platinum wire to within about $1 \mathrm{~mm}$ of its tip. Mechanically, this type of construction was satisfactory and the possibility of direct contact between the lead sealingin glass and the mercurous-sulphate paste was regarded as immaterial.

In view of the appreciable solubility of some kinds of glassware in water and in various solutions, more attention should be paid to the possibility of the glass affecting the operation of the cells. Results of tests of the solubility of glassware have been reported by various experimenters. Such determinations have little direct bearing on the problem of standard cells, but Walker ${ }^{7}$ has stated that "glasses at

\footnotetext{
1 Hulett, Phys. Rev., vol. 27, p. 337, 1908. Smith, Electrician, vol. 75, p. 463, 1915. Obata, Proc. Phys. Math. Soc. Japan, vol. 2, p. 232, 1920.

2 Wolff and Waters, B.S. Bull., vol. 4, p. 28, 1907. Shaw and Reilley, Trans. Roy. Soc. Canada, vol.

13, p. 174, 1919. Von Steinwehr, Zs. f Instrk., vol. 51, p. 522, 1931.

3 Electrician, vol. 73, p. 574, 1914; vol. 75 , p. 463, 1915.

4 Phil. Trans., vol. 229, p. 134, 1930.

5 Proc. Congres Int. d'Electricité, Paris, 2d section, Report no. 7, p. 9, 1932.

6 Hulett, Phys. Rev., vol. 32, p. 271, 1911. Wolff and Waters, B.S. Bull., vol. 2, p. 636, 1907.

7 J. Am. Chem. Soc., vol. 27, p. 872, 1905.
} 
all suitable for chemical work are much less attacked by acids than by alkalis or even water alone." The significance of this statement appears in the comparative results of neutral and acid cells.

Several kinds of glass have been used at this Bureau for the standard-cell containers, commonly called "blanks" before filling. For the most part these were soft glass with a bead of lead sealing-in glass around each platinum contact. Harder and more resistant glass, such as Pyrex, which is preferable from a chemical standpoint, could not be employed conveniently with platinum-contact wires. The platinum is not as indispensable now as formerly, because of the development of ductile tungsten wire, which can be sealed satisfactorily into Pyrex. This has made possible the use of this glass for standard-cell blanks. The results in this paper show that the emf of standard cells in Pyrex blanks with tungsten contacts are in excellent agreement with those of cells in soft glass blanks having platinum contacts. A logical extension of the work would include the use of quartz blanks. Attempts have been made to use these, but some experimental difficulties have not been overcome entirely.

Standard cells are usually designated as neutral or acid cells depending upon the neutrality or acidity of the electrolyte. For reproducible and constant values of emf it is important that the electrolyte should be uniform in hydrogen ion concentration throughout the cell. Smith ${ }^{8}$ has found that a difference in acidity at the positive and negative electrodes produces a large change in the emf of the cell. The importance of his observation, the truth of which has been substantiated in the present experiments, has apparently been overlooked. Not only are the initial values of such cells abnormal, but any inequality of acidity in various parts of the cell gives rise to changes that affect the constancy of the emf.

Since solubility of the glass containers for the cells may change appreciably the acidity of the electrolyte, we have tried adding samples of pulverized glass to the mercurous sulphate paste. In this paper it will be shown that the lead sealing-in glass, more than the other kinds, is responsible for observed changes in emf.

Besides changes caused by the alkalinity of materials derived from the glass, there is the possibility that some foreign ions dissolved from the glass may enter into the reactions in the cell. We have, therefore, made a large number of both neutral and acid cells to which we have added some compounds containing ions which might be derived from the glass as impurities to test their effect on the initial value of emf, constancy of emf, temperature coefficient, and hysteresis of the cells.

In the course of the work, modifications have been made in the design of the cell blanks employed at the Bureau. It is believed that the new blanks will materially aid in improving the constancy and portability of the cells.

\section{PREPARATION OF EXPERIMENTAL CELLS}

The method of preparing the materials and assembling the cells was in general that which has been followed at this Bureau for a number of years and which was described by Wolff and Waters ${ }^{9}$ in 1907. The materials used in the several groups of cells are given in table 1 and are further described below. 
Two samples of mercury, designated as S2 and S3 were employed. The mercury, S2, used throughout in cells 753 to 772 and 829 to 866 was, after preliminary purification, twice distilled in the Hulett ${ }^{10}$ still. Sample, S3, used in cells 791 to 805 was virgin mercury redistilled, using both vacuum and Hulett stills.

The cadmium amalgams contained 10 percent of cadmium and 90 percent purified mercury. For cells 753 to 772 the amalgam, V6, was made electrolytically, for the others cadmium metal was' alloyed with mercury by heating. The metal for the amalgam, V11, was Kahlbaum's electrolytic cadmium which was used as received. For the amalgam, V8, this electrolytic cadmium had been further purified by distilling it in an evacuated tube.

TABLE 1.-Materials used in the experimental cells

\begin{tabular}{|c|c|c|c|c|c|c|}
\hline $\begin{array}{l}\text { Cell } \\
\text { no. }\end{array}$ & Date made & Mercury & $\begin{array}{l}\text { Cadmium } \\
\text { amalgam }\end{array}$ & $\begin{array}{l}\text { Cadmium } \\
\text { sulphate }\end{array}$ & $\begin{array}{l}\text { Mercurous } \\
\text { sulphate }\end{array}$ & Glass blanks \\
\hline $753-772$ & Sept. 16, 1932 & $\begin{array}{l}\text { Redistilled, } \\
\text { S2. }\end{array}$ & $\begin{array}{l}\text { Electrolytic, } \\
\text { V6. }\end{array}$ & Commercial c.p. & $\begin{array}{l}\text { D.C. electro- } \\
\text { lytic, X4. }\end{array}$ & Glasses 23 and 30 . \\
\hline $791-796$ & Nov. 9,1932 & $\begin{array}{l}\text { Redistilled, } \\
\text { S3. }\end{array}$ & Alloyed, V8_. & $\begin{array}{l}\text { Special prepara- } \\
\text { tion, V5. }\end{array}$ & $\begin{array}{l}\text { D.C. electro- } \\
\text { lytic, X5. }\end{array}$ & Glass 21 \\
\hline $\begin{array}{l}797-802 \\
803-805\end{array}$ & -....do_. & .... do & _.... do_. & (10u do & ry de, ^o. & $\begin{array}{l}\text { Redesigned, } \\
\text { glasses } 23 \text { and } \\
30 \text {. }\end{array}$ \\
\hline $829-846$ & Jan. 31,1933 & $\begin{array}{l}\text { Redistilled, } \\
\text { S2. }\end{array}$ & Alloyed, V11_ & $\begin{array}{l}\text { tion, V6. } \\
\text { Commercial c.p. } \\
\text { recrystallized, } \\
\text { V4 }\end{array}$ & --do & Miscellaneous. \\
\hline $847-866$ & Feb. 1,1933 & ....do do & ...do. & $\sqrt{4}$ do & .....do_-- & Do. \\
\hline
\end{tabular}

The cadmium sulphate, V4, for cells 753 to 772 and 829 to 866 was recrystallized from commercial c.p. salt. The sample, V5, used in cells 791 to 802 was prepared by treating Kahlbaum's electrolytic cadmium with concentrated sulphuric acid and the salt was purified by four recrystallizations. The sample, V6, used in cells 803 to 805 was prepared by digesting the same metal with concentrated nitric acid and converting to the sulphate by adding concentrated sulphuric acid. This salt was strongly heated and recrystallized four times.

The samples of mercurous sulphate, $\mathrm{X} 4$ and $\mathrm{X} 5$, were made by direct current electrolysis. For cells 753 to 772 and 829 to 866 the salt was washed in a porcelain Gooch crucible with 6 successive portions of the saturated cadmium-sulphate solutions. For cells 791 to 805 the mercurous sulphate was first washed with 3 portions of 25 percent sulphuric acid and then with at least 3 portions of the saturated cadmium-sulphate solutions. Some of these solutions were neutral and others were acid as indicated in subsequent tables. The paste was made by mixing with the mercurous sulphate about one third to one half its volume of crushed cadmium-sulphate crystals and enough of the saturated solution to make the mixture run easily down the filling tubes. The mercurous sulphate was quite dark and showed the presence of much finely divided mercury.

In the experimental cells, to which foreign materials were added, about $0.2 \mathrm{~g}$ of each of several kinds of pulverized glass or $0.25 \mathrm{~g}$ of certain compounds were mixed with the portion of paste for each cell at the time the cells were made. The impurities added to the

10 Phys. Rev., vol. 33, pp. 4 and 314, 1911. 
various cells are listed in tables 3 to 6 . The glass samples were prepared by crushing tubing between cardboard or manila paper, and the fraction which passed through a 60-mesh sieve was strongly heated to remove traces of paper. The glasses are designated by the same numbers that Peters and Cragoe ${ }^{11}$ used in their work on the thermal dilatation of these glasses. Glass no. 28 was vacuumtube tubing imported from Germany and used for many years for cell containers made at this Bureau. A qualitative analysis showed that it contained sodium and calcium. Glass no. 23 was a Kimball sodalime tubing which has been recently used in making the soft-glass blanks. Glass no. 30 was a lead (PbO) fusing-in glass from Corning; it was used in sealing the platinum contacts into blanks made of glass no. 23. Glass no. 21 was laboratory Pyrex which has been used recently for standard-cell containers. The composition of Pyrex used differs, however, from the analysis given by Peters and Cragoe in containing less arsenic.

The chemical compounds added as impurities to the paste of cells 832 to 846 and 851 to 866 were of c.p. quality or reagent grade.

The containers used for cells 753 to 772 and 797 to 805 were of the $\mathrm{H}$-form; they were of soft glass, no. 23, with platinum contacts sealed through fusing-in glass no. 30. The H-blanks for 791 to 796 were of Pyrex no. 21 with tungsten wires. All of these cells were hermetically sealed after being filled. The containers for cells 829 to 866 were temporary blanks closed by ground-glass stoppers or corks. Some of the cells were of the inverted-Y type, others were $\mathrm{H}$-shaped.

\section{MEASUREMENTS OF ELECTROMOTIVE FORCE}

The emf of each experimental cell was determined at frequent intervals by measuring the difference between its emf and that of a "reference" cell whose value in international volts was known in terms of the Bureau's primary standard. This method, commonly known as the "opposition method", has been used at the Bureau for many years. ${ }^{12}$

In some of the more recent measurements a new standard-cell comparator designed by Brooks ${ }^{13}$ was employed. This is a specialized form of potentiometer operating on the above principle, which indicates directly the emf of a cell under test in terms of the standard to the millionth part of a volt without interpolation.

The results given in this paper are expressed, for the most part, as differences in microvolts from the Bureau's standard of emf, based on the defined value, 1.018300 international volts at $20^{\circ} \mathrm{C}$, for the Weston normal cell. A minus value indicates that the emf of the cell under test is below that of the standard. In a few instances, however, the emf of the cells are given directly in international volts.

In order to measure the emf of saturated Weston cells to the accuracy required, careful attention was given to temperature control of the oil baths in which the cells were immersed. Several of the baths were used previously by Wolff and Waters ${ }^{14}$ and, in addition, two new baths, shown in figure 1 , were also available. The smaller of

11 B.S.Sci. Papers, vol. 16, pp. 463, 464, 1920.

12 Wolff and Waters, B.S.Buli., vol. 4, p. 39, 1907.

13 The Standard Cell Comparator, a Specialized Potentiometer, B.S.Jour. Research, vol. 11 (RP 586), p. 211, August 1933.

is B.S.Bull., vol. 4, p. 33, 1807. 
these contains the primary reference standard and this bath is maintained uniformly at $28^{\circ} \mathrm{C}$, the fluctuations not exceeding $\pm 0.006^{\circ} \mathrm{C}$. The larger bath was available for measurements at temperatures ranging from $17^{\circ}$ to $35^{\circ} \mathrm{C}$.

The heating current for the oil baths was thermostatically controlled through relays and lamp banks which may be seen in figure 1 . Cooling was also provided, when necessary, by circulation of oil through a network of piping which passed through the cooling units of an automatic refrigerator and through coils submerged in the oil baths.

Measurements of the temperature of the oil baths were made with 25-ohm platinum resistance thermometers. The indications of these thermometers were reproducible to $0.002^{\circ} \mathrm{C}$. The actual temperature of the oil in which the cells were immersed was known within $0.01^{\circ}$ which corresponds to about $0.5 \mu \mathrm{v}$ in the emf of the cells.

\section{FACTORS AFFECTING THE ELECTROMOTIVE FORCE AND CONSTANCY OF CELLS}

Among the various factors which may affect the emf and constancy of standard cells, the experimental results given in this paper are limited to the effect of unequal acid concentrations and the effect of impurities derived from the glass of the container or chemical compounds added to the paste at the time the cells were made.

\section{EFFECT OF UNEQUAL ACID CONCENTRATIONS IN THE POSITIVE AND NIGATIVE LINIBS}

Smith ${ }^{15}$ has stated "that when the solution in the positive limb is made up with normal sulphuric acid (1 part of acid to 48 parts of water) the emf (of the cell) is diminished by 0.01030 volt; that when the negative limb alone contains this quantity of acid the emf is increased by 0.00965 volt; and when the whole of the solution in a cell is made up from normal acid saturated with cadmium sulphate the emf is diminished by 0.00065 volt." From this statement it is apparent that even small inequalities of the acid concentration throughout the cell may produce relatively large departures of emf from the ordinary values.

Our attention was drawn to the practical significance of Smith's statement by the behavior of cell no. 803, for which the measurements are reported in table 2 . In making this cell a solution of $N / 10$ sulphuric acid saturated with cadmium sulphate was used to fill the cell, although the mercurous-sulphate paste had been prepared with a neutral solution of cadmium sulphate. The initial value of emf of this cell was higher than the Bureau's standard of emf by $500 \mu \mathrm{v}$. From this abnormal value the emf decreased rapidly during the first month to a stable value of $-27 \mu \mathrm{v}$ which differs by only $4 \mu \mathrm{v}$ from the acid control cell, no. 805 .

Several other cells were prepared with unequal acidities in the positive and negative limbs. Cells nos. 831 and 832 contained neutral saturated solutions in the positive limbs and $N / 10$ acid solutions in the negative limbs, while cells nos. 849 and 850 contained acid solutions in the positive limbs and neutral solutions in the negative limbs. No effort was made to hinder the diffusion of the solutions in

15 See footnote 8, p. 257. 


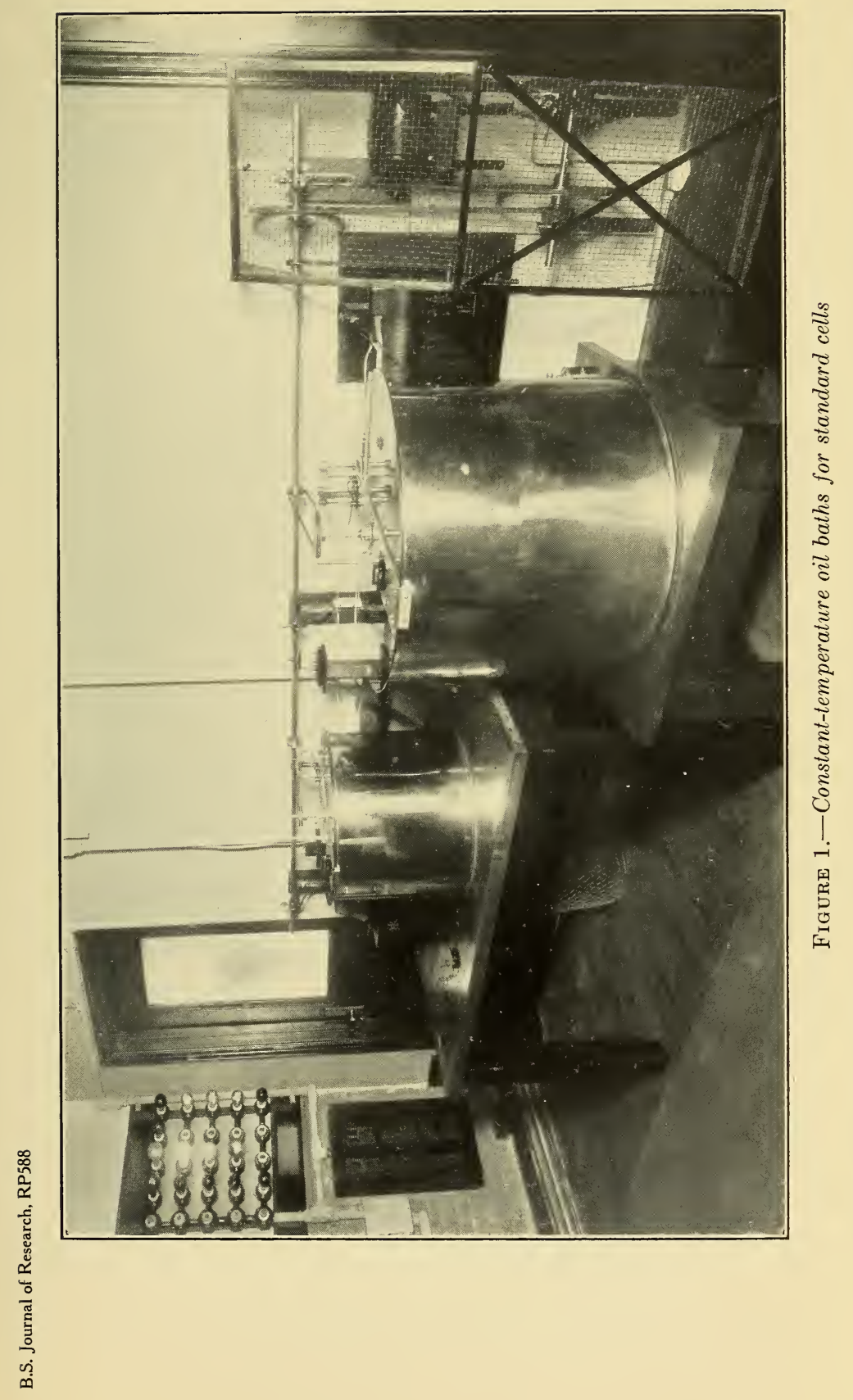


the cells. The initial values of emf were high in the case of cells nos. 831 and 832 and low for the others. The difference between the initial values of the two pairs of cells was approximately $1,000 \mu \mathrm{v}$, the high and low values being consistent with the statement by Smith.

TABLE 2.-Effect of unequal acidities in the positive and negative limbs [Differences in microvolts from B.S. standard for Weston normal cell]

\begin{tabular}{|c|c|c|c|c|c|c|c|}
\hline \multirow{2}{*}{ Age of cell } & \multirow{2}{*}{$\begin{array}{c}\text { Neutral } \\
\text { paste } \\
\text { N/10 } \\
\text { acid } \\
\text { elec- } \\
\text { trolyte } \\
\text { no. } 803\end{array}$} & \multicolumn{2}{|c|}{$\begin{array}{l}\text { Neutral positive } \\
\text { limb N/10 acid } \\
\text { negative limb }\end{array}$} & \multicolumn{2}{|c|}{$\begin{array}{l}\text { N/10 acid positive } \\
\text { limb neutral neg- } \\
\text { ative limb }\end{array}$} & \multicolumn{2}{|c|}{ Control cells } \\
\hline & & No. 831 & No. 832 & No. 849 & No. 850 & $\begin{array}{l}\text { Neutral } \\
\text { both } \\
\text { limbs, } \\
\text { no. } 804\end{array}$ & $\begin{array}{l}\mathrm{N} / 10 \text { acid } \\
\text { both } \\
\text { limbs, } \\
\text { no. } 805\end{array}$ \\
\hline $\begin{array}{l}1 \text { day } \\
2 \text { days days } \\
4 \text { days. }\end{array}$ & $\begin{array}{r}+500 \\
359 \\
262 \\
173\end{array}$ & $\begin{array}{r}+93 \\
66 \\
61 \\
56\end{array}$ & $\begin{array}{r}+275 \\
153 \\
124 \\
101\end{array}$ & 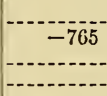 & $\begin{array}{l}-909 \\
-793 \\
-695 \\
-605\end{array}$ & $\begin{array}{r}+12 \\
18 \\
22\end{array}$ & $\begin{array}{l}-58 \\
-48 \\
-42\end{array}$ \\
\hline $\begin{array}{l}5 \text { days } \\
6 \text { days } \\
7 \text { days } \\
10 \text { days. }\end{array}$ & $\begin{array}{r}124 \\
86 \\
58 \\
18\end{array}$ & $\begin{array}{l}48 \\
46 \\
44 \\
31\end{array}$ & $\begin{array}{l}88 \\
77 \\
66 \\
45\end{array}$ & $\begin{array}{r}-370 \\
-348 \\
-\end{array}$ & $\begin{array}{l}-535 \\
-468 \\
-428 \\
-300\end{array}$ & $\begin{array}{l}24 \\
25 \\
27 \\
29\end{array}$ & $\begin{array}{l}-39 \\
-34 \\
-33 \\
-35\end{array}$ \\
\hline 15 days. 20 days. 25 days & $\begin{array}{l}-6 \\
-15 \\
-22 \\
-28\end{array}$ & $\begin{array}{l}27 \\
20 \\
18 \\
16\end{array}$ & $\begin{array}{l}27 \\
23 \\
21 \\
13\end{array}$ & $\begin{array}{r}-97 \\
-68 \\
-\end{array}$ & $\begin{array}{r}-187 \\
-125 \\
-90 \\
-70\end{array}$ & $\begin{array}{l}32 \\
33 \\
33 \\
34\end{array}$ & $\begin{array}{l}-30 \\
-30 \\
-30 \\
-30\end{array}$ \\
\hline $\begin{array}{l}2 \text { months } \\
3 \text { months } \\
5 \text { months }\end{array}$ & $\begin{array}{l}-25 \\
-27 \\
-27 \\
-27\end{array}$ & 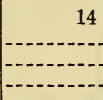 & 10 & (1) & $\left.{ }^{2}\right)$ & $\begin{array}{l}33 \\
31 \\
31 \\
30\end{array}$ & $\begin{array}{l}-31 \\
-31 \\
-31 \\
-31\end{array}$ \\
\hline
\end{tabular}

1 Contact wire broken, no further measurements.

2 Glass cracked, no further measurements.

Changes in emf of these cells were rapid as diffusion of the acid occurred. The cells having high initial values decreased and the others increased in emf continuously during several months. Unfortunately the observations on nos. 849 and 850 were terminated by mishaps before stable values were reached. All of the five cells having initial inequalities of acidity changed by large amounts compared with the control cells nos. 804 and 805 .

The difference in emf between the neutral cell, no. 804, and the $N / 10$ acid cell, no. 805 , is $61 \mu \mathrm{v}$ which tallies with Smith's ${ }^{16}$ observation that the effect of using an acid solution of cadmium sulphate, prepared by dissolving the salt in a $N / 10$ solution of sulphuric acid, is to decrease the emf of a cell by $62 \mu \mathrm{v}$.

These experiments indicate that equalization of acidity throughout the cell is an important factor in determining the initial value and constancy of emf. Small changes occurred in the control cells nos. 804 and 805 during the first few days. Large changes can be avoided by care in making the cells, but it seems likely that small fluctuations in emf, for which there is no apparent reason, may be caused by such effects as have been described above.

${ }^{16}$ Glazebrook's, Dict. of Physics, vol. 2, p. 268. 


\section{EFFECT OF GLASS ON THE CONSTANCY OF CELLS}

\section{(a) Neutral Cells}

Glass containers for standard cells may have an effect on the constancy of their emf, if the glass is appreciably soluble in the solutions contained within the cell. The amount of alkali derivable from the glass walls of the container varies with the kind of glass and the conditions of service. Ordinarily, changes in emf which might be attributed to this cause would take place so slowly that little direct information could be obtained by comparing cells in a variety of glass containers. Small changes in emf might easily be attributed to other causes. Standard cells are used over such long periods of time that it is important to investigate the effect of glass as one of the more obscure causes of variations in their emf.

In order to exaggerate the effect of the glass we have added powdered samples of several kinds of glass directly to the mercuroussulphate paste in making the cells. The powdered glasses employed in these experiments were limited to the kinds of glass which have been used at the Bureau for making the standard-cell blanks.

Table 3 gives the results of measurements on 10 neutral cells, 8 of which contained the powdered samples of glass. The remaining 2 cells were made in the customary manner to serve as control cells. The effect of the glasses, which we have designated as nos. 28,23 , and 30 , was noticed almost immediately. The mercurous sulphate in cells to which these glasses were added became discolored within 4 days and the emf of all of them was below the value of the controls.

\section{TABLE 3.-Effect of powdered glass on emf of neutral cells}

[Differences in microvolts from B. S. standard for Weston normal cell]

\begin{tabular}{|c|c|c|c|c|c|c|c|}
\hline $\begin{array}{l}\text { Cell } \\
\text { no. }\end{array}$ & $\begin{array}{l}\text { Kind of glass } \\
\text { added }\end{array}$ & $\begin{array}{c}5 \\
\text { days }\end{array}$ & $\begin{array}{c}1 \\
\text { month }\end{array}$ & $\stackrel{4}{\text { months }}$ & $\begin{array}{c}6 \\
\text { months }\end{array}$ & $\begin{array}{l}\text { Differ- } \\
\text { ence of } \\
\text { final } \\
\text { value } \\
\text { from } \\
\text { control } \\
\text { cells }\end{array}$ & $\begin{array}{l}\text { Condition of the mercurous } \\
\text { sulphate }\end{array}$ \\
\hline $\begin{array}{l}753 \\
754 \\
757 \\
758 \\
761 \\
762 \\
765 \\
766\end{array}$ & 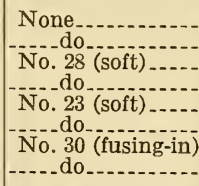 & $\begin{array}{l}+12 \\
+13 \\
-78 \\
-81 \\
-44 \\
-43 \\
-17 \\
-23\end{array}$ & $\begin{array}{l}+12 \\
+16 \\
-78 \\
-69 \\
-58 \\
-53 \\
-55 \\
-52\end{array}$ & $\begin{array}{l}+12 \\
+15 \\
-37 \\
-38 \\
-31 \\
-29 \\
-33 \\
-32\end{array}$ & $\begin{array}{l}+11 \\
+14 \\
-37 \\
-41 \\
-26 \\
-24 \\
-26 \\
-26\end{array}$ & $\begin{array}{r}-50 \\
-54 \\
-39 \\
-37 \\
-39 \\
-39\end{array}$ & $\begin{array}{l}\text { Not discolored in } 7 \text { months. } \\
\text { Do. } \\
\text { Discolored within } 4 \text { days. } \\
\text { Do. } \\
\text { Do. } \\
\text { Do. } \\
\text { Do. } \\
\text { Do. }\end{array}$ \\
\hline $\begin{array}{l}769 \\
770\end{array}$ & No. 21 (pyrex) & $\begin{array}{r}+14 \\
+8\end{array}$ & $\begin{array}{l}+2 \\
+1\end{array}$ & $\begin{array}{r}-10 \\
-9\end{array}$ & $\begin{array}{l}-27 \\
-28\end{array}$ & $\begin{array}{l}-40 \\
-41\end{array}$ & $\left\{\begin{array}{l}\text { Not discolored within } 5 \text { months; } \\
\text { slightly discolored at } 71 / 2 \\
\text { months. }\end{array}\right.$ \\
\hline
\end{tabular}

The emf of cells nos. 757 and 758 , containing glass no. 28 rose gradually during 6 months from its initial low value, but at the end of this period was still $50 \mu \mathrm{v}$ below the normal value as given by the control cells nos. 753 and 754 .

The cells nos. $761,762,765$, and 766 containing the powdered-glass samples, nos. 23 and 30 , were also found to have emf below the normal value, but not as low initially as for the cells mentioned in the preceding paragraph. The emf fell rapidly during the first month, reached minimum values and then increased during the succeeding months, as shown in figure 2. There seems to be a close analogy 
between the behavior of these cells and a group of 14 neutral cells, nos. 687 to 700 , which have been under observation for 4 years. These earlier cells were made in blanks consisting of the glass designated above as no. 23 for the walls and cross arms and no. 30 for sealing in the platinum wires. The cells nos. 687 to 700 were made according to the usual procedure at the Bureau and contained no foreign materials.

Figure 2 shows that the average emf of these 14 cells decreased during the first year and increased during succeeding years by about the same amounts as in the case of the experimental cells nos. 761 , 762,765 , and 766 , within a few months. The time required for the glass to produce such changes was much shorter, under the exaggerated conditions in the experimental cells. The evidence of this experiment and others reported in subsequent paragraphs indicates that the lead fusing-in glass is likely to be most immediate in its effects and, the most harmful. In 1911 M. P. Shoemaker and E.C.McKelvy at this Bureau set up one cell in a blank made entirely of lead glass. After 28 months this cell had decreased in emf by $178 \mu$ v while two other cells made with the same materials in blanks ordinarily employed (German vacuumtube tubing) had changed by only -13 and $+3 \mu \mathrm{v}$, respectively, in the same period of time.

The emf of cells nos. 769 and 770 , containing the powdered Pyrex glass which we have called no. 21, was initially nearer the

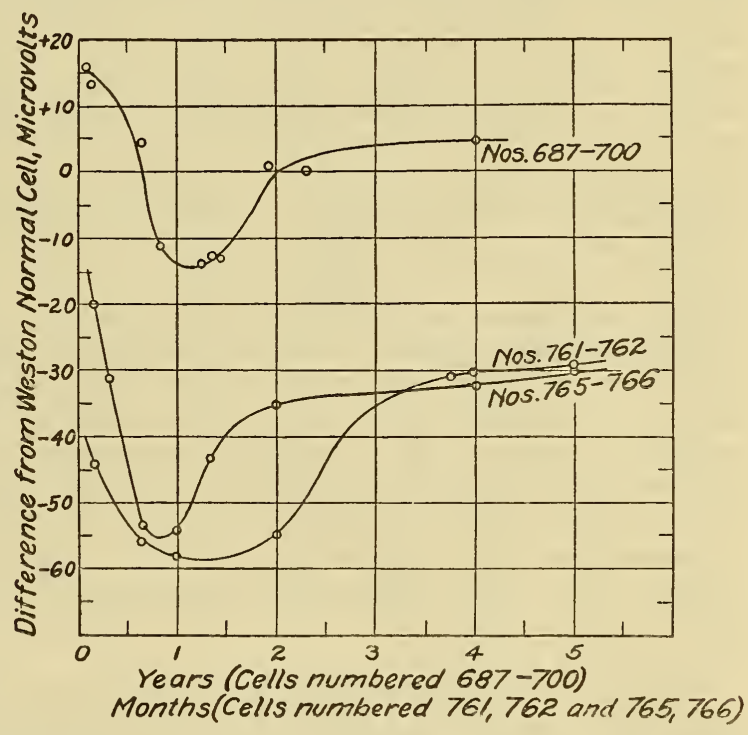

FIGURE 2.-Comparison of changes in emf of experimental cells containing powdered glass (nos. 761, 762, 765, and 766) with those of neutral cells prepared in the customary manner (nos.687 to 700). emf of the control cells than any of the others, but has fallen continuously during 6 months. Unlike the cells previously discussed, no discoloration of the paste was observed until 7 months had elapsed, indicating that hydrolysis was taking place more slowly than in the other cells to which softer glasses were added.

Table 3 shows that at the end of 6 months the emf of all of the cells to which powdered glass was added have approached a value about $40 \mu \mathrm{v}$ below that of the control cells, nos. 753 and 754 .

In attempting to give a theory for the behavior of these cells, consideration must be given to three facts: (1) The visible discoloration of the paste, (2) the low initial values of emf, and (3) the subsequent increase in emf. 
The mercurous-sulphate paste in all cells to which glass was added showed a discoloration indicating that the glass was a cause of hydrolysis of the mercurous sulphate. Gouy ${ }^{17}$ has found, as other observers have also, that mercurous sulphate is hydrolyzed by water, forming a nearly insoluble basic salt having a yellowish-green color. In the present experiments the hydrolysis of the mercurous sulphate within the cell seems to have been accelerated as a result of alkalinity derived from the glass.

The low initial values of the emf of cells to which the powdered glass was added can probably be explained as a result of the hydrolysis of the mercurous sulphate. Statements in the literature, however, about the effect of hydrolyzed mercurous sulphate on the initial emf of cells containing such material are contradictory. Smith ${ }^{18}$ has stated that a cell containing only hydrolyzed salt is 0.02 volt lower in emf than a corresponding cell with the usual mercurous sulphate depolarizer. Vosburgh and Elmore ${ }^{19}$ have studied the behavior of neutral cells made with mercurous sulphate which had been washed with water or a dilute sodium-carbonate solution before the cells were set up. They assume that such treatment hydrolyzed the particles of mercurous sulphate on the surface and they observed a change in color of the salt which was treated with the dilute carbonate solution. Their measurements extended over a period of 15 months during which the cells containing mercurous sulplate washed with water began with high initial values of emf which decreased subsequently, but the other cells containing mercurous sulphate washed with the carbonate solution began with low values of emf, and these continued to fall throughout the experiment. Hager and Hulett ${ }^{20}$ prepared a cell containing hydrolyzed mercurous sulphate, which had a rapidly decreasing emf. Their measured values were all much below the value for the Weston normal cell. The high initial value which they give for this cell is based on an extrapolation over a period of 7 weeks. All of the above-mentioned authors have shown that cells containing hydrolyzed mercurous sulphate usually have low values of emf which continue to fall during long periods of time.

The emf of the cells containing the glass did not continue to fall indefinitely (except in case of cells nos. 769 and 770 for reasons mentioned above), but rose decidedly as shown in figure 2. At least part of the decrease in emf initially must have been due to the acid condition of the paste as a result of the $\mathrm{H}_{2} \mathrm{SO}_{4}$ formed by hydrolysis. In accordance with Smith's statement (p.260) a higher acidity in the positive limb than in the negative limb results in an emf lower than normal. When the acid formed in the paste has had time to diffuse to other parts of the cell, the acidity throughout the cell becomes more nearly uniform. An increase in emf would be expected and this has been found in our experiments. It seems likely that considerable information could be obtained by exploring the acidity of the electrolyte in various parts of the cell by the use of the glass electrode.

17 Comptes Rendus, vol. 130, p. 1400,1900

18 Glazebrook's Dictionary of Physics, vol. 2, p. 269.

19 J. Am. Chem. Soc., vol. 53, p. 2828, 1931.

20 J. Phys. Chem., vol. 36, p. 2098, 1932. 


\section{(b) ACID CELLS}

The results of similar experiments with $N / 10$ acid cells are given in table 4. At the end of 7 months these cells presented an appearance in striking contrast to the neutral group. No discoloration of the mercurous sulphate was observable in any of these cells, but rather large changes in emf occurred, nevertheless. The cells nos. 759 to 760,763 to 764 , and 767 to 768 all began with abnormally high values of emf which changed very rapidly during the first month. The cells containing the lead fusing-in glass no. 30 were particularly bad in this respect and at the end of 6 months were still far from normal values. The other cells, however, approached normal values for $N / 10$ acid cells and at the end of 6 months were all within $10 \mu \mathrm{v}$ of the controls. The action of the acid in preventing hydrolysis of the mercurous sulphate in the presence of grossly exaggerated quantities of glass and the close approach of the emf of these cells to normal values may explain the reason why some experimenters have considered the acid cells to be more stable than neutral cells.

TABLE 4.-Effect of powdered glass on emf of N/10 acid cells [Differences in microvolts from B.S. standard for Weston normal cell]

\begin{tabular}{|c|c|c|c|c|c|c|c|}
\hline $\begin{array}{l}\text { Cell } \\
\text { No. }\end{array}$ & Kind of glass added & 5 days & 1 month & 4 months & 6 months & $\begin{array}{l}\text { Differ- } \\
\text { ence of } \\
\text { final } \\
\text { value } \\
\text { from } \\
\text { control } \\
\text { cells }\end{array}$ & $\begin{array}{c}\text { Condition of the mercurous } \\
\text { sulphate }\end{array}$ \\
\hline $\begin{array}{l}755 \\
756 \\
847 \\
848\end{array}$ & \begin{tabular}{|l|} 
None \\
\end{tabular} & $\begin{array}{l}-59 \\
-29 \\
-56 \\
-54\end{array}$ & $\begin{array}{l}-52 \\
-48 \\
-49 \\
-48\end{array}$ & $\begin{array}{c}-52 \\
-53 \\
\end{array}$ & $\begin{array}{l}-52 \\
-52 \\
--.\end{array}$ & 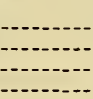 & $\begin{array}{l}\text { Not discolored in } 7 \text { months. } \\
\text { Do. } \\
\text { Do. } \\
\text { Do. }\end{array}$ \\
\hline $\begin{array}{l}759 \\
760 \\
763 \\
764\end{array}$ & $\begin{array}{l}\text { No. } 28 \text { (soft) } \ldots . . . . . . \\
\text { No. } 23 \text { (soft) } \\
\end{array}$ & $\begin{array}{l}+41 \\
+34 \\
+46 \\
+59\end{array}$ & $\begin{array}{l}-47 \\
-47 \\
-29 \\
-46\end{array}$ & $\begin{array}{l}-42 \\
-48 \\
-50 \\
-45\end{array}$ & $\begin{array}{l}-45 \\
-48 \\
-43 \\
-46\end{array}$ & $\begin{array}{l}+7 \\
+4 \\
+9 \\
+6\end{array}$ & $\begin{array}{l}\text { Do. } \\
\text { Do. } \\
\text { Do. } \\
\text { Do. }\end{array}$ \\
\hline $\begin{array}{l}767 \\
768 \\
771 \\
865 \\
866\end{array}$ & $\begin{array}{l}\text { No. } 30 \text { (fusing-in) } \\
\text { No. } 21 \text { (pyrex) } \\
\text { do do }\end{array}$ & $\begin{array}{r}+337 \\
+524 \\
+6 \\
-43 \\
-51\end{array}$ & $\begin{array}{r}+158 \\
+421 \\
-28 \\
-49 \\
-55\end{array}$ & $\begin{array}{r}+51 \\
+121 \\
-43 \\
\end{array}$ & $\begin{array}{r}+33 \\
+57 \\
-41 \\
\end{array}$ & $\begin{array}{r}+85 \\
+109 \\
+9 \\
0 \\
-6\end{array}$ & $\begin{array}{l}\text { Do. } \\
\text { Do. } \\
\text { Do. } \\
\text { Do. } \\
\text { Do. }\end{array}$ \\
\hline
\end{tabular}

The behavior of the acid cells nos. 767 and 768 containing powdered glass, no. 30 , indicates that this lead fusing-in glass has a much more deleterious effect on the cells than the other kinds of glass which were tried in these experiments.

The behavior of the $N / 10$ acid cells containing glass is more easily explained than in the case of the neutral cells. Because of the acid concentration it may be assumed that hydrolysis of the mercurous sulphate did not occur. The effect of the powdered glass in the paste was undoubtedly to reduce the acidity of the electrolyte in the positive limb so that the cells may be considered in the light of Smith's statement quoted on page 260 . The effective acidity in the negative limb being higher than in the positive limb, an initially high emf could be expected and this was found in the experiments. Diffusion processes would tend to equalize the acidity throughout the cells and cause a decrease in the emf, which would eventually reach values approximately equal to or slightly greater than the value for the N/10 acid control cells. The results of the experiment have verified this theory. 


\section{EFFECT OF MATERIALS ADDED AS IMPURITIES TO THE PASTE}

The relatively large changes in emf produced by adding powdered samples of glass to the mercurous-sulphate paste (see tables 3 and 4) suggested the desirability of testing the effect of certain chemical compounds on the emf and constancy of the cells. Cadmium oxide was selected as one of the compounds to be added since this material would produce a basic condition in the paste. The other materials which were selected included ions, such as lead and sodium, which might be derived from the various kinds of glass which have been employed in constructing the cell blanks.

With no information to guide us in choosing the amount of such materials to be incorporated with the paste, it was decided to add equal quantities of each material. Samples of $0.5 \mathrm{~g}$ were added, therefore, to the respective portions of the mercurous-sulphate paste for each pair of cells. The actual amount of a particular impurity placed in each cell was approximately 0.25 g. Such an amount obviously exaggerated the conditions which might exist in any ordinary cell, but the relative effects indicated those substances which are likely to be the most harmful.

Sixteen cells, nos. 829, 830, and 833 to 846 were made January 31, 1933. We shall refer to these as neutral cells although the condition of neutrality was doubtless modified by the addition of the various impurities. The mercurous sulphate was washed with a neutral saturated solution of cadmium sulphate before adding the impurity and the electrolyte was initially, at least, a neutral solution of cadmium sulphate. These cells included 2 controls, nos. 829 and 830, to which no impurities were added and 7 pairs of cells containing oxides of cadmium and lead; sulphates of aluminum, calcium, sodium, and magnesium; and boric acid, respectively. A second group of 16 cells which we shall designate as $N / 10$ acid cells for analogous reasons, was made in a similar manner on February 1, 1933. The detailed results for these groups are given in tables 5 and 6 .

\section{(a) NEUTRAL CELLS}

Considering first the neutral cells, table 5 , the values for the control cells at the end of 7 weeks are normal and in good agreement with other cells similarly made without the addition of foreign materials. The cells to which cadmium oxide was added increased in emf initially, attained maximum values at the end of 3 weeks and then the emf decreased rapidly. The cells to which lead oxide (litharge) was added were lower in emf than the control cells by about $1,000 \mu \mathrm{v}$ on the second day. From this low initial value, the emf decreased with extraordinary rapidity to values approximately $20,000 \mu \mathrm{v}$ below normal. Aluminum sulphate produced smaller effects than the other impurities which we have tested. Sodium sulphate, on the other hand, caused a large decrease in emf initially, but subsequent measurements showed a rapid increase to more nearly normal values. Magnesium sulphate in one cell, no. 838, produced results analogous to those of the cells containing sodium sulphate, but in the other cell, no. 837, the rise and fall of the emf has surpassed in magnitude any changes which we have ever observed previously. Boric acid resulted in abnormally high initial values of emf. 
TABLE 5.-Effect of impurities on emf of neutral cells

\begin{tabular}{|c|c|c|c|c|c|c|c|c|}
\hline \multirow{2}{*}{$\begin{array}{l}\text { Cell } \\
\text { no. }\end{array}$} & \multirow{2}{*}{$\begin{array}{l}\text { Impurities added to the } \\
\text { paste }\end{array}$} & \multicolumn{6}{|c|}{$\begin{array}{l}\text { Differences in microvolts from B.S. standard for } \\
\text { Weston normal cell }\end{array}$} & \multirow{2}{*}{$\begin{array}{c}\text { Differ- } \\
\text { ence } \\
\text { of final } \\
\text { value } \\
\text { from } \\
\text { control } \\
\text { cells }\end{array}$} \\
\hline & & 2 days & 3 days & 1 week & 3 weeks & 5 weeks & 7 weeks & \\
\hline 829 & Tone -. & $\begin{array}{l}-11 \\
-44\end{array}$ & $\begin{array}{l}-6 \\
=39\end{array}$ & +9 & +15 & +15 & $\begin{array}{r}+17 \\
+17\end{array}$ & \\
\hline 833 & $\mathrm{Cadn}$ & $\begin{array}{l}-44 \\
+41\end{array}$ & $\begin{array}{l}-32 \\
+46\end{array}$ & $\begin{array}{r}-3 \\
+79\end{array}$ & $\begin{array}{l}+14 \\
+75\end{array}$ & $\begin{array}{l}+16 \\
+47\end{array}$ & $\begin{array}{l}+17 \\
+22\end{array}$ & t \\
\hline 834 & $c^{-}$ & 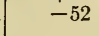 & & -16 & +32 & +4 & -198 & -2 \\
\hline 835 & ide $(\mathrm{PbO})$ & -713 & $-1,180$ & $-7,742$ & $-19,450$ & $-20,560$ & $-20,744$ & $-20,761$ \\
\hline 836 & $\ldots d$ & $-1,272$ & $-2,284$ & $-16,294$ & -19 & & & $-18,9$ \\
\hline 84 & Alum & -3 & -2 & $\begin{array}{l}-64 \\
-64\end{array}$ & $\begin{array}{l}-14 \\
-28\end{array}$ & $\begin{array}{l}-13 \\
-24\end{array}$ & $\begin{array}{l}-10 \\
-23\end{array}$ & $\begin{array}{l}-27 \\
-40\end{array}$ \\
\hline 83 & Calci & +278 & +220 & +154 & & + & +81 & + \\
\hline & & & & & & +1 & & +85 \\
\hline & Soldi & 27 & 88 & 06 & 0 & -269 & -163 & -180 \\
\hline 84 & & & 7 & 4 & 1,070 & -523 & -266 & -28 \\
\hline 837 & Magr & $-28,000$ & 26,000 & $-1,500$ & $+9,200$ & $-22,000$ & $-300,000$ & $-300,00$ \\
\hline $83 \varepsilon$ & & $-1,167$ & -869 & -340 & -127 & -84 & -70 & -87 \\
\hline $\begin{array}{l}843 \\
844\end{array}$ & Boric & $\begin{array}{r}+398 \\
+409\end{array}$ & $\begin{array}{r}+412 \\
+408\end{array}$ & $\begin{array}{r}+412 \\
+375\end{array}$ & $\begin{array}{l}+221 \\
+247\end{array}$ & $\begin{array}{l}+20 \\
+58\end{array}$ & $\begin{array}{l}-17 \\
-117\end{array}$ & $\begin{array}{l}-34 \\
-134\end{array}$ \\
\hline & & & & & & & & \\
\hline
\end{tabular}

TABLE 6.-Effect of impurities on emf of N/10 acid cells

\begin{tabular}{|c|c|c|c|c|c|c|c|c|}
\hline \multirow{2}{*}{$\begin{array}{l}\text { Cell } \\
\text { no. }\end{array}$} & \multirow{2}{*}{$\begin{array}{l}\text { Impurities added to the } \\
\text { paste }\end{array}$} & \multicolumn{6}{|c|}{$\begin{array}{l}\text { Differences in micror olts from B.S. standard for } \\
\text { Weston normal cell }\end{array}$} & \multirow{2}{*}{$\begin{array}{l}\text { Differ- } \\
\text { ence } \\
\text { of final } \\
\text { value } \\
\text { from } \\
\text { control } \\
\text { cells }\end{array}$} \\
\hline & & 2 days & 3 days & 1 week & 3 weeks & 5 weeks & 7 weeks & \\
\hline 847 & None & -96 & -71 & -55 & -50 & -48 & -45 & \\
\hline $\begin{array}{l}848 \\
851\end{array}$ & Cadmium oxide & $\begin{array}{r}-97 \\
+878\end{array}$ & $\begin{array}{r}-71 \\
+922\end{array}$ & $\begin{array}{r}-54 \\
+990\end{array}$ & $\begin{array}{r}-48 \\
+905\end{array}$ & $\begin{array}{r}-45 \\
+714\end{array}$ & $\begin{array}{r}-46 \\
+640\end{array}$ & +686 \\
\hline 852 & , & +918 & +956 & $+1,009$ & +970 & +806 & +750 & +796 \\
\hline 853 & Lead oxide $(\mathrm{PbO})$ & $+1,008$ & $+1,021$ & +991 & +716 & +627 & +840 & \\
\hline 854 & $\cdots$ & +975 & $+1,016$ & $+1,034$ & +925 & +906 & $+1,267$ & $+1,313$ \\
\hline $\begin{array}{l}859 \\
860\end{array}$ & Aluminum sulphate- & $\begin{array}{l}-155 \\
-98\end{array}$ & $\begin{array}{r}-118 \\
-90\end{array}$ & $\begin{array}{l}-74 \\
-78\end{array}$ & $\begin{array}{l}-68 \\
-73\end{array}$ & $\begin{array}{l}-68 \\
-71\end{array}$ & $\begin{array}{l}-68 \\
-70\end{array}$ & -24 \\
\hline 857 & Calcium sulphate. & -28 & -31 & -33 & -35 & -42 & -38 & +8 \\
\hline 858 & nheta & $\begin{array}{r}+16 \\
-6,370\end{array}$ & $\begin{aligned}-21 \\
-6\end{aligned}$ & $\begin{array}{r}-43 \\
-6.162\end{array}$ & $\begin{array}{r}-50 \\
-1-300\end{array}$ & $\begin{array}{r}-53 \\
-205\end{array}$ & $\begin{array}{r}-55 \\
-1170\end{array}$ & -124 \\
\hline $\begin{array}{l}805 \\
864\end{array}$ & $\begin{array}{l}\text { Sodium } \\
\text { - do }\end{array}$ & $\begin{array}{l}-0,224 \\
-6,224\end{array}$ & $\begin{array}{l}-0,24 i \\
-6,186\end{array}$ & $\begin{array}{l}-0,102 \\
-4,471\end{array}$ & $-1,060$ & $\begin{array}{l}-205 \\
-179\end{array}$ & $\begin{array}{l}-100 \\
-137\end{array}$ & $\begin{array}{l}-124 \\
-91\end{array}$ \\
\hline 855 & Magnesium sulphate_. & -413 & -268 & -155 & -110 & -89 & -87 & -41 \\
\hline 856 & --..dc & -920 & -575 & $\begin{array}{l}-235 \\
+214\end{array}$ & -125 & -99 & -93 & $\begin{array}{r}-47 \\
-140\end{array}$ \\
\hline 862 & Boric ac & $\begin{array}{l}+246 \\
+303\end{array}$ & $\begin{array}{l}+252 \\
+310\end{array}$ & $\begin{array}{l}+214 \\
+282\end{array}$ & $\begin{array}{r}+89 \\
+163\end{array}$ & $\begin{array}{l}-65 \\
-68\end{array}$ & $\begin{array}{l}-186 \\
-128\end{array}$ & -140 \\
\hline
\end{tabular}

\section{(b) ACID CELLS}

Table 6 gives the results on a similar group of cells which we have designated as $N / 10$ acid cells. The control cells in this group are numbered 847 and 848 . The emf of these cells at the end of 7 weeks was $62 \mu \mathrm{v}$ below the value of the controls of the neutral group, table 5. This difference is entirely normal for the difference in acidity of the two groups. The initial value of emf of cells nos. 851 and 852 containing cadmium oxide and nos. 853 and 854 containing lead oxide was initially high as might have been predicted from the statement of Smith (p. 260). With some fluctuations, the emf of these cells have remained higher than normal by 700 to $1,300 \mu \mathrm{v}$. Comparing the cells to which leadoxide was added with the corresponding 
group of neutral cells, the changes in emf have been relatively small. Aluminum and calcium sulphates produced little effect. Sodium sulphate in these $N / 10$ acid cells produced changes in emf of about the same magnitude as in the corresponding neutral cells.

The maximum changes in emf of the N/10 acid cells during the course of the measurements are less on the average than those shown in table 5 for the neutral group.

Distinct changes in the color of the paste of some cells became evident soon after the cells were made. An examination of all cells at the end of 4 weeks disclosed marked discoloration of the paste in the cells (both acid and neutral) to which cadmium oxide and lead oxide had been added. None of the other cells showed any evidence of discoloration of the mercurous-sulphate paste.

The neutral cells containing cadmium oxide, nos. 833 and 834, showed bright greenish yellow spots in the paste at the end of 4 weeks, but the appearance has changed somewhat since that time. The last examination, 14 weeks after the cells were made, showed a yellow discoloration of the paste next to the cadmium sulphate crystals and a greenish-yellow color adjacent to the mercury. The corresponding acid cells containing cadmium sulphate also showed bright greenish yellow spots when the cells were examined at the end of 4 weeks, but on reexamination 10 weeks later the bright color had disappeared and the paste had returned to nearly the same color as that in the control cells.

Similar examinations of the cells containing lead oxide have been made and color changes observed which are indicative of chemical reactions proceeding in the paste. In the neutral cells nos. 835 and 836 , bright greenish yellow discolorations were observed. Orangecolored spots were noticeable in the paste adjacent to the cadmiumsulphate crystals. These discolorations persisted during the succeeding 10 weeks, but they were somewhat darker at the end of this time. In the acid cells, some greenish-yellow discoloration was observed, but the most noticeable feature was the layer of white or light bluish green paste adjacent to the mercury. In these acid cells this discoloration has since faded, and the paste has returned to the normal gray color. The emf of these cells has not returned to normal, however. At the end of 3 months it was about $700 \mu \mathrm{v}$ above the value of the control cells.

While the color changes occurring in the paste may be taken as an indication of secondary reactions which may affect the emf, large changes in emf have been observed in cells without any visible evidence of hydrolysis of the salt.

It is probably more than a coincidence that lead fusing-in glass was the most harmful of the samples of glass which were tested and lead oxide the most harmful of the various chemical compounds, with the possible exception of the somewhat anomalous results with magnesium sulphate.

The initial effects of the other materials (except magnesium sulphate) seem to wear off with time, and the emf of cells containing these materials approached normal values after a few weeks.

The cells which were made up with $N / 10$ acid solutions of cadmium sulphate seem to be slightly less sensitive to the effects of various impurities than the corresponding neutral cells.

It does not seem possible now to offer a theory which is sufficient to explain all of the observed facts. The practical result of the 
investigation indicates clearly, however, certain steps which must be taken to improve the reproducibility and constancy of the Weston normal cell as a standard of emf.

\section{EFFECT OF IMPURITIES ON HYSTERESIS AND TEMPERATURE COEFFICIENT}

In order to study hysteresis effects and temperature coefficients of cells which do not have a constant emf when maintained at constant temperatures, it is necessary to define clearly such terms as drift and hysteresis and to distinguish these from the temperature coefficient. The meaning of these terms is shown graphically in figure 3.

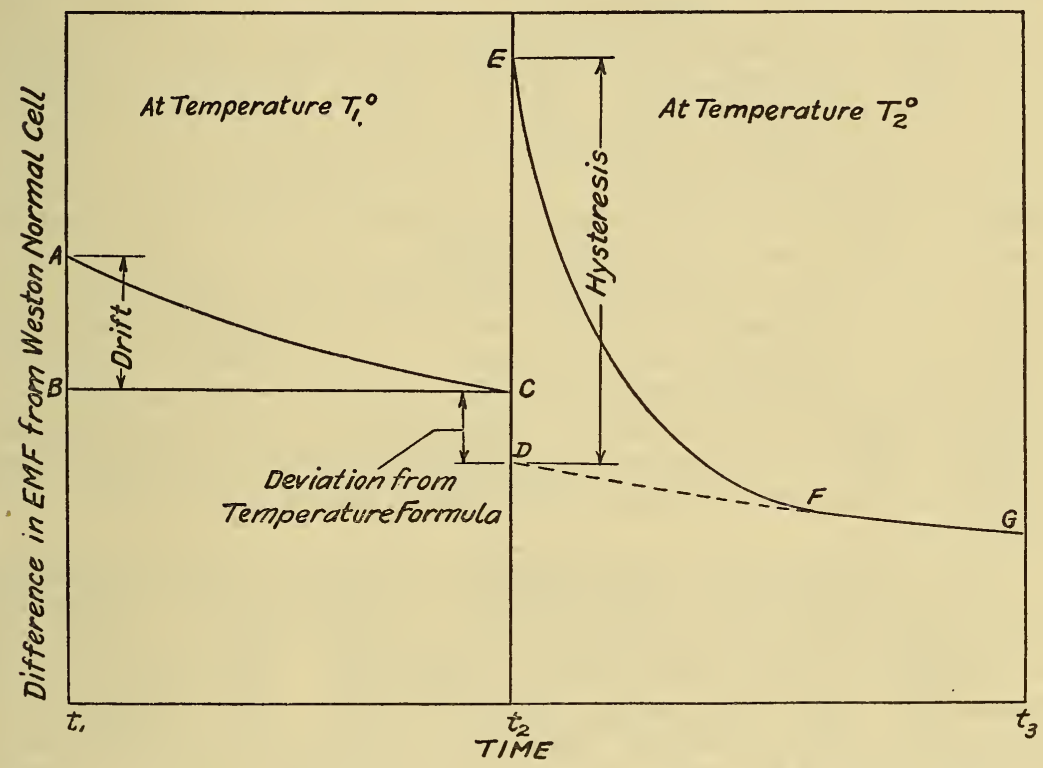

Figure 3.-Diagram to illustrate the meaning of the terms "drift", "hysteresis" and "deviation from temperature formula."

The progressive change in emf which occurs while a cell is kept at a constant temperature is called "drift". In figure 3 the drift from time $t_{1}$ to $t_{2}$ is $A B$.

After an abrupt change in temperature, a cell may have an abnormal emf before reaching the value characteristic of the new temperature. This temporary deviation from its normal value is known as "hysteresis." In figure 3 the abnormal values of the emf which should be attributed to hysteresis lie between $E$ and $F$, while from $F$ to $G$ the changes are due to drift. The point $F$ is located somewhat arbitrarily where the curvature becomes approximately the same as for the previously observed changes in emf at temperature $T_{1}$. In order to determine the initial hysteresis at the time the temperature was changed the drifting emf $G F$ must be extrapolated to $D$ which is the value the cell would have had if there had been no hysteresis; the observed hysteresis is therefore given by $D E$. 
A definite change in emf of the Weston normal cell is associated with each temperature interval to which the cell is subjected. The international temperature formula ${ }^{21}$-expresses this relation between emf and temperature for most neutral and N/10 acid cells. The emf of many of our experimental cells, however, deviated considerably from the values calculated by using the formula. Thus in tables 7 and 8 the data designated "deviation from the temperature formula" are the differences between the observed change in emf and the calculated change given by the temperature formula. In figure 3 , the ordinates are differences in emf from the Weston normal cell at temperatures $T_{1}$ and $T_{2}$. The deviation from the temperature formula is thus given by $C D$.

In making the tests for hysteresis and deviation from the temperature formula the cells were removed from a bath at $28.0^{\circ} \mathrm{C}\left(T_{1}\right)$ and plunged into a second bath at $20.0^{\circ} \mathrm{C}\left(T_{2}\right)$. The initial readings at $20.0^{\circ} \mathrm{C}$ were taken when the cells had been in the second bath for 1 hour. The values for hysteresis and deviation from the temperature formula given in tables 7 and 8 were determined from graphs similar to figure 3 . The values given for the cells containing the powdered glass were probably correct to $\pm 2 \mu \mathrm{v}$, except for cells nos. 767 and 768 for which values could not be determined closer than $\pm 8 \mu \mathrm{v}$. The values for most of the cells containing added chemical compounds were determined to about $\pm 5 \mu \mathrm{v}$. Cells for which the errors were probably larger were no. 851 and $852, \pm 10$; no. $854 \pm 25$; and nos. 835 and $836 \pm 100 \mu \mathrm{v}$. The values of the hysteresis and deviation from the temperature formula given for cell no. 853 are only approximations because of the extraordinary shape of the curve for this cell.

From a consideration of the data given in tables 7 and 8 it is evident that the hysteresis was larger for neutral cells than for the corresponding acid cells except for the groups to which fusing-in glass no. 30 and cadmium oxide were added as impurities. The reason for the anomalous results with these cells is not known. Omitting these two groups, the average value of the hysteresis of neutral cells was about five times that of the acid cells. No such striking difference between the temperature coefficients of neutral and acid cells was observved except in the case of cells to which lead oxide was added. The neutral cells showed a coefficient of about $+200 \mu \mathrm{v}$ per ${ }^{\circ} \mathrm{C}$, while the acid cells deviated less than $10 \mu v$ per degree from the value given by the temperature formula.

In nearly all cases the cells containing added foreign materials showed larger hysteresis and greater deviation from the international temperature formula than did the control cells to which no such materials were added. The detailed results of these experiments are given in tables 7 and 8 .

Hysteresis in standard cells has been attributed to a variety of causes. It is generally known that old cells have more hysteresis than newly made cells as stated by Eppley. ${ }^{22}$ Our results indicate that the glass may be responsible, in part, for this effect.

21 Schedule C, Report of the International Conference on Electrical Units and Standards.

22 J. Frank. Inst., vol. 201, p. 44, 1926. 
TABLE 7.-Hysteresis and deviation from temperature formula of cells containing samples of powdered glass

[Values given in microvolts]

\begin{tabular}{|c|c|c|c|c|c|c|c|}
\hline \multicolumn{4}{|c|}{ Neutral cells } & \multicolumn{4}{|c|}{$N / 10$ acid cells } \\
\hline $\begin{array}{l}\text { Cell } \\
\text { No. }\end{array}$ & Glass added & $\begin{array}{c}\text { Hyster- } \\
\text { esis }\end{array}$ & $\begin{array}{l}\text { Deviation } \\
\text { from tem- } \\
\text { perature } \\
\text { formula }\end{array}$ & $\begin{array}{l}\text { Cell } \\
\text { No. }\end{array}$ & Glass added & $\begin{array}{l}\text { Hyster- } \\
\text { esis }\end{array}$ & $\begin{array}{l}\text { Deviation } \\
\text { from tem- } \\
\text { perature } \\
\text { formula }\end{array}$ \\
\hline $\begin{array}{l}753 \\
754 \\
757 \\
758 \\
761 \\
762 \\
765 \\
766 \\
769 \\
770\end{array}$ & $\begin{array}{l}\text { None } \\
\text { No. } 28 \text { (soft) } \\
\text { No. } 23 \text { (soft) } \\
\text { No. } 30 \text { (fusing-in) } \\
\text { No. } 21 \text { (Pyrex) } \\
-{ }_{-} \text {do }\end{array}$ & $\begin{array}{r}+8 \\
+6 \\
+6 \\
+63 \\
+11 \\
+15 \\
0 \\
-4 \\
+106 \\
+65\end{array}$ & $\begin{array}{l}-3 \\
-3 \\
+7 \\
+15 \\
+3 \\
+3 \\
+2 \\
+4 \\
-7 \\
-5\end{array}$ & $\begin{array}{l}755 \\
756 \\
759 \\
760 \\
763 \\
764 \\
767 \\
768 \\
771 \\
865 \\
865\end{array}$ & $\begin{array}{l}\text { None-1ond } \\
\text { No. } 28 \text { (soft) } \\
\text { No. } 23 \text { (soft) } \\
\text { No. } 30 \text { (fusing-in) } \\
\text { No. } 21 \text { (Pyrex) } \\
- \text { do }\end{array}$ & $\begin{array}{r}+2 \\
0 \\
+13 \\
+19 \\
+6 \\
+9 \\
+100 \\
+60 \\
+3 \\
+3 \\
+9\end{array}$ & $\begin{array}{l}-6 \\
-3 \\
-10 \\
-13 \\
+2 \\
-3 \\
-85 \\
-15 \\
-2 \\
-7 \\
-6\end{array}$ \\
\hline
\end{tabular}

TABLE 8.-Hysteresis and deviation from temperature formula of cells containing added impurities

[Values given in microvolts]

\begin{tabular}{|c|c|c|c|c|c|c|c|}
\hline \multicolumn{4}{|c|}{ Neutral cells } & \multicolumn{4}{|c|}{$N / 10$ acid cells } \\
\hline $\begin{array}{l}\text { Cell } \\
\text { No. }\end{array}$ & Impurities added & $\begin{array}{c}\text { Hystere- } \\
\text { sis }\end{array}$ & $\begin{array}{l}\text { Devia- } \\
\text { tion from } \\
\text { tempera- } \\
\text { ture for- } \\
\text { mula }\end{array}$ & $\begin{array}{l}\text { Cell } \\
\text { No. }\end{array}$ & Impurities added & $\begin{array}{c}\text { Hystere- } \\
\text { sis }\end{array}$ & $\begin{array}{l}\text { Devia- } \\
\text { tion from } \\
\text { tempera- } \\
\text { ture for- } \\
\text { mula }\end{array}$ \\
\hline $\begin{array}{l}829 \\
830 \\
833 \\
834\end{array}$ & 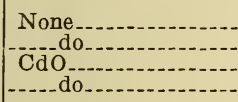 & $\begin{array}{r}+10 \\
+9 \\
-12 \\
-11\end{array}$ & $\begin{array}{r}-3 \\
-3 \\
0 \\
+35\end{array}$ & $\begin{array}{l}847 \\
848 \\
851 \\
852\end{array}$ & 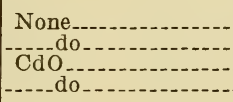 & $\begin{array}{r}-1 \\
0 \\
+117 \\
+121\end{array}$ & $\begin{array}{l}-3 \\
-1 \\
-71 \\
-71\end{array}$ \\
\hline $\begin{array}{l}835 \\
836 \\
841 \\
842\end{array}$ & {$\left[\begin{array}{c}\mathrm{PbO}_{2} \\
\hdashline \mathrm{Al}_{2}\left(\mathrm{SO}_{4}\right)_{3} \\
-\ldots \mathrm{do}_{\ldots}\end{array}\right.$} & $\begin{array}{r}+625 \\
+1,300 \\
+36 \\
+37\end{array}$ & $\begin{array}{r}-1,690 \\
-2,370 \\
+2 \\
+5\end{array}$ & $\begin{array}{l}853 \\
854 \\
859 \\
860\end{array}$ & $\mathrm{PbO}^{\mathrm{Pb}}$ & $\begin{array}{r}+200 \\
+170 \\
-3 \\
-1\end{array}$ & $\begin{array}{r}-75 \\
+10 \\
+8 \\
-3\end{array}$ \\
\hline $\begin{array}{l}839 \\
840 \\
845 \\
846\end{array}$ & \begin{tabular}{c}
$\mathrm{CaSO}_{4-\ldots}$ \\
$-\mathrm{Na}_{2} \mathrm{SO}_{4-\ldots}$ \\
\hdashline$-\mathrm{do}_{4}$
\end{tabular} & $\begin{array}{r}+130 \\
+131 \\
-57 \\
-40\end{array}$ & $\begin{array}{l}+46 \\
+35 \\
+16 \\
+39\end{array}$ & $\begin{array}{l}857 \\
858 \\
863 \\
864\end{array}$ & $\begin{array}{l}\mathrm{CaSO}_{4-\ldots} \\
-\mathrm{Na}_{2} \mathrm{SO}_{4}-\ldots \\
-\end{array}$ & $\begin{array}{r}+50 \\
0 \\
+17 \\
0\end{array}$ & $\begin{array}{l}-17 \\
+1 \\
-2 \\
+2\end{array}$ \\
\hline $\begin{array}{l}837 \\
838 \\
843 \\
844\end{array}$ & $\begin{array}{r}\mathrm{MgSO}_{4-} \\
-\mathrm{H}_{3} \mathrm{BO}_{3} \\
- \\
-\end{array}$ & $\begin{array}{r}0 \\
+26 \\
+37\end{array}$ & $\begin{array}{r}+8 \\
-29 \\
-36\end{array}$ & $\begin{array}{l}855 \\
856 \\
861 \\
862\end{array}$ & \begin{tabular}{c}
$\mathrm{MgSO}_{4-}$ \\
\hdashline $\mathrm{H}_{3} \mathrm{BO}_{3}-$ \\
-
\end{tabular} & $\begin{array}{r}-3 \\
-3 \\
+15 \\
+15\end{array}$ & $\begin{array}{l}+5 \\
+5 \\
-20 \\
-15\end{array}$ \\
\hline
\end{tabular}

\section{IMPROVEMENTS IN THE DESIGN OF STANDARD-CELL BLANKS}

The $\mathrm{H}$-shaped containers shown in figure $4(A)$ have been used at the Bureau for some time. The limbs and cross arm were made of soft glass no. 23, and the platinum contact wires were sealed in with glass no. 30 . In order to make the seal strong, the contact wire was covered with a sleeve of fusing-in glass. The exposed platinum tip was always beneath the surface of the mercury or the amalgam, but the fusing-in glass often extended into the mercurous-sulphate or cadmium-sulphate crystals. Because of the marked effect which the sample of powdered fusing-in glass had on the constancy of emf, this 
type of construction was changed in the new blanks shown in figure $4(B)$. A special point was made of locating this fusing-in glass as near the lower extremities of the cells as possible, in order that the fusing-in glass should not be in direct contact with the mercuroussulphate paste or the cadmium-sulphate crystals. The fusing-in glass could be entirely covered by mercury in the positive limb and by the cadmium amalgam in the negative limb.

is

The slight constrictions of the glass in the older type of blank have been changed to sharp constrictions ${ }^{23}$ which are located about $4 \mathrm{~mm}$ higher on the positive than on the negative limb. The layers of crystals of cadmium sulphate extend through these constrictions, and since the crystals eventually form compact masses they are firmly held in place. This makes the cells more portable and pre-

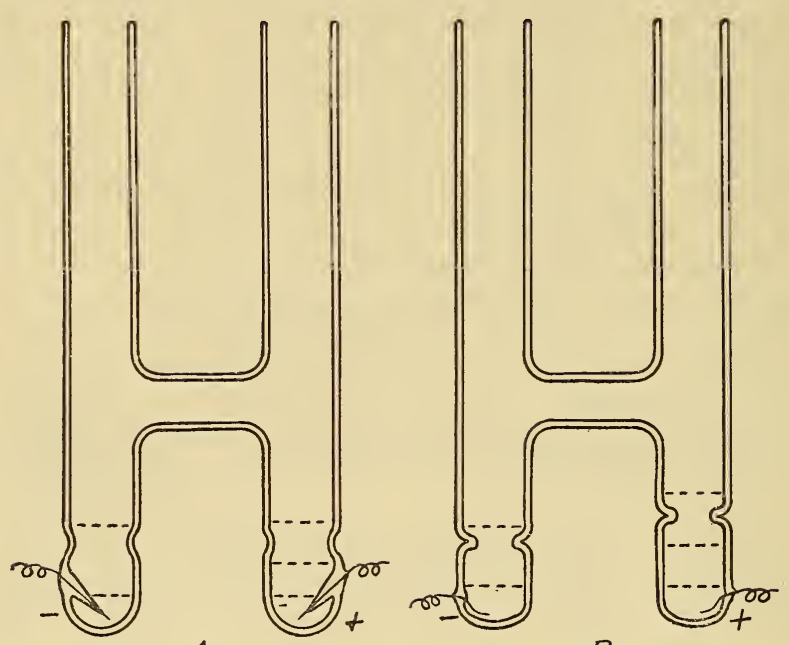

$A$

Type $A$ formerly used and type $B$ the redesigned blank.

these cells, nos. 791 to 796 , were made with Pyrex-glass blanks Six of tungsten wires sealed through the glass walls to make contact with the electrodes.

The other four cells were made with soft-glass blanks, using the glass which we have designated as no. 23 for the walls and cross arms and the minimum possible amount of the fusing-in glass no. 30 for sealing in the platinum wires.

The emf of these cells are given in table 9. Little significance need be attached to the small changes occurring during the first month, but it is especially significant that changes occurring between 1 month and 6 months have been smaller than those of the groups of cells nos. 687 to 700 , as shown by figure 2 . We could cite other examples also showing that the changes in emf of newly made cells generally exceed those indicated in table 9.

There is little difference in the constancy of the neutral and acid cells, notwithstanding the often repeated statement that neutral cells are not as constant as acid cells. Priepke and Vosburgh ${ }^{24}$ have sug-

${ }^{23}$ This type of constriction has been used successfully at the National Physical Laboratory.

24 J.Am.Chem. Soc., vol. 55, p. 1804, 1933. 
gested recently using buffered electrolytes in standard cells to increase the constancy of their emf. Their buffered cells were more constant than their unbuffered cells, but the latter changed in emf by unusually large amounts during 6 months. Comparing the results of their buffered cells with the results of the Bureau's cells which were made in the usual manner and therefore unbuffered, a greater degree of constancy of the Bureau's cells (both acid and neutral) is shown by the results in table 9 .

TABLE 9.-Comparison of cells in redesigned glass blanks

NEUTRAL CELLS

\begin{tabular}{|c|c|c|c|c|c|c|}
\hline \multirow{2}{*}{$\begin{array}{l}\text { Cell } \\
\text { no. }\end{array}$} & \multirow{2}{*}{ Kind of blank } & \multicolumn{5}{|c|}{$\operatorname{Emf} 28^{\circ} \mathrm{C}$} \\
\hline & & 7 days & 1 month & 2 months & 4 months & $\begin{array}{c}6 \\
\text { months }\end{array}$ \\
\hline $\begin{array}{l}791 \\
792 \\
793 \\
797 \\
798\end{array}$ & $\begin{array}{l}\text { Pyrex blank- } \\
\text { Soft-glass blank- do }\end{array}$ & $\begin{array}{r}1.017942 \\
933 \\
942 \\
1.017943 \\
940\end{array}$ & $\begin{array}{r}1.017946 \\
945 \\
946 \\
1.017944 \\
941\end{array}$ & $\begin{array}{r}1.017944 \\
945 \\
945 \\
1.017943 \\
941\end{array}$ & $\begin{array}{r}1.017944 \\
945 \\
946 \\
1.017944 \\
941\end{array}$ & $\begin{array}{r}1.017944 \\
\hdashline 1.017945 \\
\hdashline 943\end{array}$ \\
\hline
\end{tabular}

N/10 ACID CELLS

\begin{tabular}{|c|c|c|c|c|c|c|}
\hline $\begin{array}{l}794 \\
795 \\
796 \\
799 \\
800\end{array}$ & $\begin{array}{l}\text { Pyrex blank. } \\
\text { Soft-glass blank }\end{array}$ & $\begin{array}{r}1.017874 \\
888 \\
880 \\
1.017882 \\
890\end{array}$ & $\begin{array}{r}1.017879 \\
891 \\
888 \\
1.017887 \\
888\end{array}$ & $\begin{array}{r}1.017884 \\
887 \\
886 \\
1.017886 \\
886\end{array}$ & $\begin{array}{r}1.017884 \\
887 \\
886 \\
1.017885 \\
886\end{array}$ & $\begin{array}{r}1.017880 \\
888 \\
888 \\
1.017883 \\
885\end{array}$ \\
\hline
\end{tabular}

It is not possible to give the 6 months' readings for cells nos. 792 and 793, because of mechanical failures. The former became partially filled with oil because of a defect in sealing the glass and no. 793 became inoperative by breaking the tungsten wire. Both of these defects can be overcome.

It is especially important to notice that the results in table 9 indicate close agreement inemf of the cells in soft glass with platinum leads and in Pyrex glass with tungsten leads.

\section{DISCUSSION OF THE RESULTS}

Glass containers for Weston normal cells may have a greater effect on the constancy of emf of the cells than has previously been suspected. We have found evidence that mercurous-sulphate paste when in contact with an excess of certain kinds of glass becomes hydrolyzed visibly in a short time in "neutral" cadmium-sulphate solution. It has been possible, therefore, to accelerate changes in emf of cells by adding glass in powdered form to the paste. The observed changes in emf of these cells during several months closely paralleled the behavior of cells, prepared in the usual way, during several years.

The changes in emf of our neutral cells with time did not follow the curves given by Shaw, Reilley, and Clark, ${ }^{25}$ but our observations

25 Phil. Trans., vol. 229, p. 129, 1930. 
on the experimental cells and other groups to which we have referred have not covered as long a period of time as that of their experiments. The Bureau has records of neutral cells which were made 25 years or more ago. Many of these have changed in emf in much the same way as our experimental cells; that is, initial decreases in emf were followed by increases to values reasonably constant during a long period of time. Although a change ${ }^{26}$ in the unit of emf has been made since these cells were constructed, it is possible to trace back the emf in terms of the present basis of reference. Such figures are given for one of these early cells, no. 191, which is still in daily use.

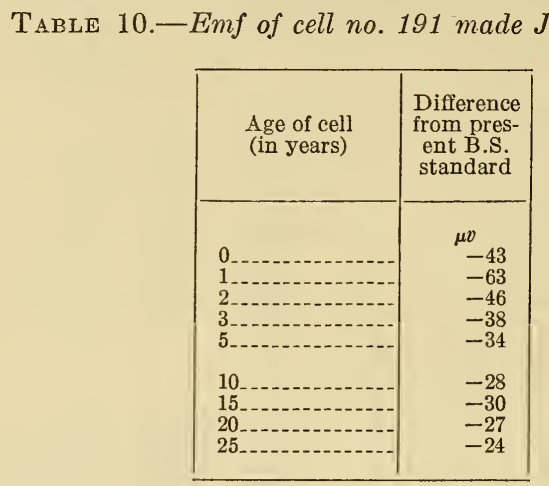

The record of these early cells considered in the light of the present experiment raises again the question whether mercurous sulphate is continuously hydrolyzed in a neutral cadmium-sulphate solution, provided no external agency, such as the glass walls of the container, causes such a reaction.

The presence of various impurities in the mercurous-sulphate paste produced changes in hysteresis and temperature coefficient of some of the cells. Old cells are known to have greater hysteresis than new cells and there is some reason for believing that changes in temperature coefficient occur also. Our experiments indicate that it is possible to accelerate the experimental work by studying the effect of adding various materials to the paste, but in any repetition of the experiments reported in this paper it will be possible to choose more judiciously the quantities of such materials to be incorporated with the pa.te.

Although the cells made in the redesigned glass blanks have been measured for only a few months the present indications are that an improvement has been made. The Bureau expects to continue this series of experiments and to use, if possible, containers of fused quartz, although the number of cells which can be made in such containers may be limited.

\section{SUMIMARY}

Some glass containers for standard cells have been found to have an appreciable effect on the constancy of emf of the cells.

It has been found possible to accelerate the effect of the glass by incorporating samples in powdered form in the mercurous-sulphate paste.

${ }_{26}^{26}$ B.S. Circular No. 29, 1911. 
Neutral and $N / 10$ acid cells containing the powdered glass have been compared with cells prepared in the usual manner and similarities in the behavior found.

Various impurities have been added to the paste of experimental cells and some surprisingly large changes in emf observed.

Hysteresis of standard cells, which is known to change somewhat with age of the cell, was also affected to a marked extent by the various impurities added to the mercurous-sulphate paste. Some changes in the temperature coefficient of emf were noted also.

\section{ACKNOWLEDGMENT}

The authors wish to acknowledge indebtedness to Mrs. D. N. Craig, who prepared the materials for, and assisted in, making cells nos. 687 to 700 .

Washington, May 16, 1933. 